\title{
Peningkatan Berpikir Kritis pada Mata Pelajaran Sejarah Melalui Pendekatan Pembelajaran Konstruktivistik
}

\author{
Oleh : Rudi Hermanto \\ Pendidikan Sejarah PPS UNJ
}

\begin{abstract}
This study aims to determine the effect of constructivist learning approach on improving critical thinking skills and learning outcomes of learners history. The method used in this study is action research method to the design of the spiral model Kemmis and Taggart. The instruments used are the guidelines for the observation of critical thinking skills and learn the history of the test results. Subjects were students of class XII IPS 3 SMA Negeri 42 Jakarta totaling 33 people. The results are: (1) Application of constructivist learning approach can improve critical thinking skills and learning outcomes of the History of learners ; (2) Planting material concepts through constructivist learning model can accelerate and facilitate the understanding of the learners; (3) Through the constructivist learning approach learners are becoming increasingly active in finding and exploring new knowledge; (4) In the process constructivist learning approach to attract learners in studying the history lesson .
\end{abstract}

Key words: history learning outcomes, constructivist instructional approaches, improved critical thinking

\begin{abstract}
Abstrak
Penelitian ini bertujuan untuk mengetahui pengaruh pendekatan pembelajaran konstruktivistik pada peningkatan kemampuan berpikir kritis dan hasil belajar sejarah peserta didik. Metode penelitian yang digunakan dalam penelitian ini adalah metode action research dengan desain model spiral Kemmis dan Taggart. Instrumen yang digunakan adalah pedoman pengamatan untuk kemampuan berpikir kritis dan tes hasil belajar sejarah. Subjek penelitian adalah peserta didik kelas XII IPS 3 SMA Negeri 42 Jakarta yang berjumlah 33 orang. Hasil penelitian: (1) Penerapan pendekatan pembelajaran konstruktivistik dapat meningkatkan kemampuan berpikir kritis dan hasil belajar Sejarah pada peserta didik; (2) Penanaman konsep materi melalui model pembelajaran konstruktivistik dapat mempercepat dan mempermudah pemahaman para peserta didik; (3) Lewat pendekatan pembelajaran konstruktivistik peserta didik kian aktif dalam mencari dan menggali pengetahuan baru; (4) Dalam prosesnya pendekatan pembelajaran konstruktivistik mampu menarik minat peserta didik dalam mempelajari mata pelajaran sejarah
\end{abstract}

Kata Kunci: hasil belajar sejarah, pendekatan pembelajaran konstruktivistik, peningkatan berpikir kritis

\section{PENDAHULUAN}

Berpikir adalah proses terpenting dalam kehidupan setiap kehidupan manusia. Sepanjang hayatnya manusia akan terus selalu melakukan aktivitas berpikir. Kemampuan berpikir seseorang dapat berasal dari dalam dirinya sendiri, namun kemampuan tersebut juga dapat dilatih dan dikembangkan sehingga menjadi sebuah kemampuan yang berbeda antar tiap individu. Berpikir memungkinkan setiap orang untuk dapat merepresentasikan dunia sebagai model dan memberikan perlakuan terhadapnya secara efektif sesuai dengan tujuan, rencana, dan keinginannya. Berpikir melibatkan kemampuan otak 
untuk mengolah segala informasi, seperti saat kita membentuk konsep, terlibat dalam pemecahan masalah, melakukan penalaran, dan mengambil keputusan.

Intilligent memory merupakan bagian atau fungsi yang terdapat dalam bagian otak kiri manusia. Intilligent memory menyimpan segala bentuk kemampuan berpikir. Kemampuan individu agar dapat berhasil dalam kehidupannya ditentukan oleh kecakapan berpikirnya dalam memecahkan masalah-masalah dalam kehidupan. Kemampuan berpikir kritis merupakan salah satu dasar yang wajib dimiliki oleh manusia. Piaget memaparkan bahwa berpikir kritis adalah keterampilan setiap individu dalam menggunakan strategi berpikir dalam menganalisis argumen dan memberikan interpretasi berdasarkan persepsi yang benar dan rasional. Onions menambahkan, berpikir kritis merupakan salah satu cara atau keterampilan dalam berpikir yang mendorong seseorang mendapatkan informasi secara sistemik dan diputuskan lewat pertimbangan yang logis.

Sejarah merupakan mata pelajaran yang fungsinya menumbuh kembangkan cara berpikir kritis bagi setiap peserta didik. Untuk apa belajar dan memahami sejarah ? Karena lewat sejarahlah manusia dapat mengkonsepsikan kehidupan dalam perjalanan waktu yang terus berjalan. Menempatkan diri kita dalam perjalanan waktu itu sudah merupakan kebutuhan setiap manusia. Namun dalam realitasnya, pendidikan sejarah di Sekolah Menengah Atas (SMA) memiliki banyak problem. Pembelajaran sejarah di tingkat Sekolah Menengah Atas (SMA) kurang begitu mendapatkan apresiasi positif dari setiap peserta didik di sekolah.
Peserta didik menganggap mata pelajaran sejarah kurang menyenangkan atau tanpa variasi. Pembelajaran sejarah juga sering berjalan satu arah (monoton), guru terus memberikan materi dengan ceramah tanpa melihat potensi yang dimiliki oleh para peserta didik.

Kemampuan berpikir kritis para peserta didik tidak berkembang dengan baik karena mereka kurang diberikan ruang untuk memaparkan pandangan serta analisisnya ketika pem-belajaran berlangsung. Pengajaran masih dipakai oleh para guru sebagai paradigma utama, semua proses penyampaian hanyalah sebagai transfer materi semata, bukan sebagai tansformasi nilai. Melihat fenomena ini, paradigma pengajaran harus diubah menjadi paradigma pembelajaran yang mengedepankan proses pengembangan potensi diri peserta didik. Guru sejarah harus mampu menciptakan inovasi baru dalam pembelajaran sejarah, dan wajib memiliki kompetensi yang baik dalam memaparkan makna atau intisari yang terkandung dari setiap materi yang disampaikan.

Idealnya pembelajaran sejarah adalah wahana bagi setiap peserta didik untuk berpikir jauh lebih kritis, mampu memahami makna atau nilai dari setiap peristiwa yang pernah terjadi, bukan sekedar mengingat tokoh, fakta, dan tahun kejadian. Esensi terpenting, dalam setiap peristiwa sejarah yang pernah terjadi, peserta didik diharapkan mampu untuk mengambil nilai-nilai positif yang patut untuk diteladani. Oleh sebab itu paradigma pem-belajaran yang terfokus kepada guru kini harus diubah, pembelajaran yang berpusat kepada peserta didik merupakan perubahan yang paling tepat. 
Driscoll menyatakan bahwa pembelajaran merupakan upaya yang disengaja untuk mengelola kejadian atau peristiwa belajar dalam memfasilitasi peserta didik sehingga memperoleh tujuan yang dipelajari, suatu rencana yang terorganisasi untuk mengembang-kan optimalisasi hasil belajar para peserta didik. Oleh karenanya, menurut Reigeluth dan Chellman, pembelajaran dapat dipahami sebagai segala sesuatu yang dilakukan dengan maksud untuk memfasilitasi belajar. Melalui penjelasan tersebut, maka dapat dipahami bahwa pembelajaran adalah seluruh mekanisme dan proses belajar yang dilaksanakan oleh para guru kepada peserta didik dengan melibatkan seluruh komponen pembelajaran untuk mendukung tercapainya tujuan belajar.

Pembelajaran sejarah wajib terselenggara lewat forum dialogis, guru dan peserta didik wajib melakukan riset secara bersama. Atau dengan kata lain siswa bukan hanya menghafal faktafakta berkelanjutan, melainkan mampu menjawab fakta dan efek yang saling terkait. Dari pembahasan ini dapat dijabarkan bahwa proses pembelajaran intinya adalah aktivitas belajar para peserta didik. Aktif atau tidaknya aktivitas pembelajaran dipengaruhi oleh banyak aspek, salah satunya adalah pendekatan pembelajaran yang diterapkan oleh para guru di kelas.

\section{METODOLOGI PENELITIAN}

Metode yang diterapkan dalam penelitian ini adalah penelitian kaji tindak atau sering dikenal dengan action research. Penelitian ini dilakukan untuk menganalisis keberhasilan atau kegagalan dalam suatu aktivitas pembelajaran. Penelitian ini diharapkan mampu untuk meningkatkan mutu pembelajaran di tingkat Sekolah Menengah Atas.
Action research atau penelitian tindakan adalah salah satu bentuk rancangan penelitian. Dalam penelitian tindakan peneliti mendeskripsikan, menginterpretasi dan menjelaskan suatu situasi sosial pada waktu yang bersamaan dengan melakukan perubahan atau intervensi dengan tujuan perbaikan atau partisipasi. Menurut Gay, Mills dan Airasian, penelitian tindakan adalah suatu rangkaian kegiatan bersama yang berkelanjutan antara pihak terkait dalam hal merencanakan, melaksanakan, dan mengevaluasi rangkaian upaya untuk mencapai perubahan status pola pikir, pandangan, cara kerja, dan sikap baru yang didasari sebagai tindakan yang bersifat dinamis terhadap perubahan selanjutnya.

Koshy menyatakan bahwa penelitian tindakan selalu berhubungan dengan tindakan untuk mencapai hasil praktis dan menciptakan bentuk pemahaman baru, karena tindakan tanpa pengetahuan adalah buta dan teori tanpa tindakan hanyalah hal yang tak berarti. Penelitian tindakan ditujukan untuk memberikan andil pada pemecahan masalah praktis dalam situasi problematik yang mendesak dan pada pencapaian tujuan ilmu sosial melalui kolaborasi patungan dalam rangka kerja etis yang saling berterima. Proses penelitian bersifat dari waktu ke waktu. Dengan demikian action research menghubungkan antara teori dengan praktek.

Penelitian tindakan bertujuan untuk menyelesaikan suatu problem yang terjadi pada sebuah lembaga. Dalam menyelesaikan problem tersebut dapat dilakukan lewat tindakan tertentu. Lembaga yang akan menjadi objek penelitian adalah SMA Negeri 42 Jakarta, tepatnya di Jakarta Timur, DKI Jakarta. Penelitian ini dilakukan pada 
mata pelajaran Sejarah di kelas XII IPS 3. Penelitian berlangsung selama tiga bulan, dimulai pada bulan Oktober sampai Desember 2015.

\section{Prosedur Penelitian Tindakan}

Desain penelitian sendiri mengacu padapendapatKemmisdan Taggart. Model spiral penelitian yang diusulkan oleh Kemmis dan Taggart bersifat self-reflective, artinya penggunaan model tersebut dapat dimodifikasi dan diadaptasi sesuai dengan kebutuhan yang ada. Siklusnya mencakup: Perencanaan, pelaksanaan, observasi dan refleksi. Adapun siklussiklus di atas dapat digambarkan dalam bentuk spiran pada halaman berikut:

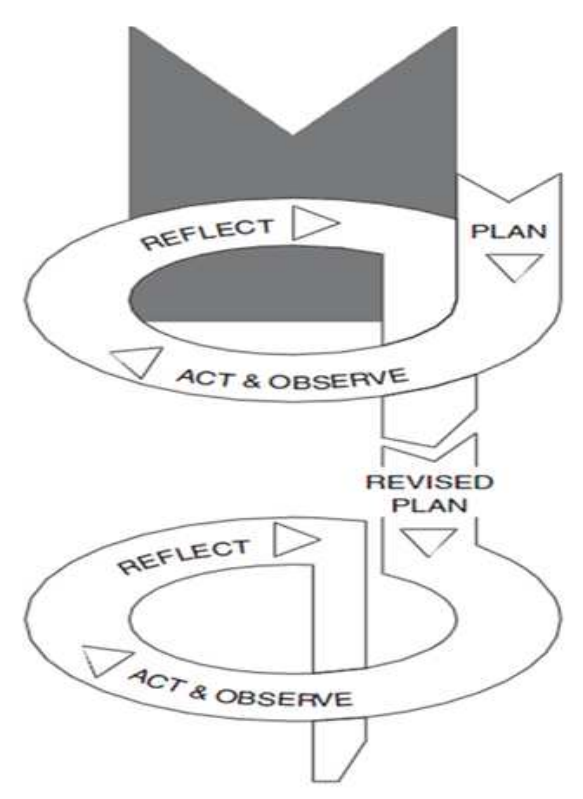

Gambar 1. Model Kemmis dan aggart (2004: 24)

Siklus dalam penelitian ini dirancang melalui tahapan-tahapan sebagai berikut:

Pertama, peneliti mengindentifikasi permasalahan yang terkait dengan peningkatan berpikir para peserta didik. Identifikasi masalah dilakukan agar peneliti dapat menemukan solusi atau pemecahan masalah yang kelak akan dihadapi.

Kedua, menentukan solusi berupa bentuk tindakan yang akan diterapkan dalam usaha pe-mecahan masalah. Bentuk tindakan yang akan diterapkan pada siklus pertama adalah penerapan pendekatan pembelajaran konstruktivistik.

Ketiga, membuat rancangan tindakan. Pendekatan pembelajaran konstruktivistik diterapkan pada mata pelajaran Sejarah dengan mengutamakan hal-hal berikut ini : 1) guru beserta peserta didik akan mendiskusikan suatu topik, 2) materi yang ditentukan harus menimbulkan rasa tanda tanya, 3) aktivitas pembelajaran harus mampu meningkatkan berpikir kritis para peserta didik.

Keempat, menjalankan rancangan tindakan siklus. Aplikasi tindakan dilakukan oleh guru kelas dan dimonitor oleh peneliti secara berkelanjutan dengan menggunakan instrumen yang telah disediakan.

Kelima, melakukan monitoring serta evaluasi. Monitoring serta evaluasi dilakukan untuk mengetahui sejauh mana bentuk tindakan yang sedang dijalankan.

Keenam, merefleksi hasil tindakan siklus pertama untuk membuat rekomendasi apakah tindakan ini dihentikan atau dilanjutkan pada siklus selanjutnya.

\section{HASIL DAN PEMBAHASAN}

1. Observasi Tindakan Siklus I

Dalam tahap ini observasi dilakukan untuk melihat serta mengetahui intervensi yang telah dijalankan. Deskripsinya dapat dilihat dalam uraian ini :

a. Meningkatnya Kemampuan Berpikir Kritis Peserta Didik 
Peningkatan berpikir kritis peserta didik diukur lewat instrumen aktivitas pem-belajaran yang terdiri dari tujuh butir indikator. Setiap butir indikator tersebut terdapat kolom atau tempat untuk diceklis oleh peneliti.

\section{Pertemuan Pertama :}

Dari hasil observasi yang diperoleh oleh peneliti, sebagian kecil peserta didik telah dapat merumuskan masalah, memberikan argumen, memberikan tanggapan atas pernyataan teman. Sebagian besar peserta didik belum mampu menunjukkan adanya peningkatan aktivitas berpikir kritis.

\section{Pertemuan Kedua :}

Aktivitas pembelajaran mulai mengalami adanya perubahan ke peningkatan berpikir kritis.

Untuk pendahuluan, berdasarkan refleksi antara guru dan peneliti, ada beberapa hal yang terjadi dalam penerapan pendekatan pembelajaran konstruktivistik yang perlu diperhatikan, antara lain:

a. Dalam melakukan absensi, guru terkadang memberikan jokes yang membuat waktu pem-belajaran sedikit ter-buang, jokes memang diperlukan untuk men-cairkan suasana, tapi ada menejemen waktu dalam aktifitas pem-belajaran.

b. Perhatian peserta didik belum terfokus saat pembelajaran dimulai, hal ini terjadi karena mata pelajaran berlangsung di jam terakhir, saat dimana energi dan konsentrasi peserta didik sudah terkuras.

c. Keterlibatan peserta didik dalam aktivitas pembelajaran belum berjalan secara maksimal. Terkesan, keterlibatan peserta didik hanya terfokus kepada beberapa orang yang memang menyukai mata pelajaran ini.
Juga ada sebagian dari peserta didik yang belum berani me-nyampaikan pandangannya karena terlihat malumalu.

d. Kiranya perlu dilakukan revisi untuk siklus berikutnya terkait pada bagian pendahuluan. Hal ini diperlukan unuk menumbuhkan serta mengembangkan semangat belajar para peserta didik

\section{Revisi ini antara lain adalah :}

a, Pendahuluan tidak hanya dilakukan dengan cara pemberian jokes saja. Guru dapat memulai pembelajaran dengan mengkaitkan kajian materi hari itu dengan konteks yang terjadi pada masa sekarang.

b. Keterlibatan peserta didik tidak harus selalu dengan pola tanya jawab, namun perlu dilakukan dengan pemberian tugas pada hari sebelumnya agar merangsang dan memfokuskan perhatian mereka dalam proses awal pembelajaran.

Untuk penyajian, pada siklus I guru telah berupaya membuka ruang dan kesempatan bagi peserta didik untuk membangun sendiri pengetahuannya. Hal ini dilakukan agar mereka dapat mengembangkan kemampuan berpikir kritisnya dalam proses pembelajaran. Penerapan pendekatan pembelajaran konstruktivistik pada dasarnya mampu untuk mengembangkan pola berpikir kritis para peserta didik. Hal ini dibuktikan dengan peserta didik mampu melalui tahapan-tahapan indikator berpikir kritis. Walau demikian, ada beberapa hal yang perlu diperhatikan dalam tahap penyajian pada siklus I, antara lain :

a. Meskipun materi yang diberikan adalah materi yang menimbulkan sisi investigasi (menggali lebih dalam), beberapa peserta didik masih nampak 
sulit dalam menyelesaikan masalah yang dihadapi.

b. Teamwork antar kelompok terlihat belum optimal. Artinya, terdapat anggota kelompok yang ter-lampau mendominasi, dan jarang memberikan kesempatan kepada teman sekelompoknya.

c. Peserta didik yang menjadi kelompok penyaji terlihat masih kurang percaya diri ketika memberikan presentasi di depan kelas.

d. Peserta didik masih terpaku pada smart phone dalam mencari sumber atau data saat proses pembelajaran berlangsung.

e. Kiranya perlu dilakukan revisi untuk siklus berikutnya terkait pada bagian penyajian.

\section{Revisi ini meliputi hal-hal sebagai berikut :}

a. Mungkin dibutuhkan media visual seperti film untuk menyajikan materi yang lebih menarik dan dapat merangsang fokus peserta didik dalam fokus pembelajaran.

b. Memberikan motivasi kepada setiap kelompok agar tampil dengan ranah kerjasama, bukan one man show.

c. Meningkatkan sikap toleransi dalam kehidupan kelas, tidak cuek dan menghargai kelompok penyaji saat memberikan presentasinya.

d. Menyiapkan sumber literature lain kepada peserta didik.

Pada bagian penutup, untuk selanjutnya guru perlu meminta peserta didik untuk memberikan saran dan kritik demi perbaikan kualitas pembelajaran berikutnya. Saran dan kritik para peserta didik sebaiknya disampaikan secar tertulis tanpa mencantumkan nama mereka (tertutup).
Terdapat beberapa hal yang perlu direkomendasikan sebagai tindak lanjut untuk perbaikan siklus selanjutnya terkait dengan peningkatan kemampuan berpikir kritis melalui pendekatan pembelajaran konstruktivistik, sebagai berikut :

a. Guru dan peneliti wajib memberikan ruang serta kesempatan seluasluasnya kepada para peserta didik dalam memberikan argumen atau pandangannya dalam proses pembelajaran.

b. Guru dan peneliti perlu memotivasi keberanian peserta didik dalam menyampaikan argumen atau pandangannya dalam forum diskusi.

c. Guru dan peneliti selanjutnya akan meng-ubah pola kebiasaan, yang sebelumnya mendominasi kelas menjadi mem-berdayakan kelas, artinya memberikan kesempatan kepada setiap peserta didik untuk meningkatkan kemampuannya.

d. Guru dan peneliti akan menyampaikan setiap hasil observasi kepada peserta didik tentang perkembangan aktifitas mereka pada pertemuan selanjutnya.

e. Aktivitas belajar peserta didik dalam proses pembelajaran adalah acuan indikator keberhasilan meningkatnya kemampuan berpikir kritis. Semakin banyak partisipasi peserta didik dalam berargumen, mem-beri tanggapan, me-lakukan analisis, men-jawab pertanyaan dengan logis, merupakan hal-hal yang menunjukkan bahwa kemampuan berpikir kritis mereka mulai meningkat.

Untuk lebih memacu para peserta didik dalam proses pembelajaran, maka guru dan peneliti akan melakukan beberapa hal ini untuk siklus selanjutnya : a. Memberikan reward atau penghargaan kepada peserta didik yang aktif dalam proses pembelajaran, hal ini penting 
agar mereka semakin terpacu lagi dalam kajian selanjutnya.

b. Memotivasi peserta didik yang kurang aktif untuk menjadi lebih aktif agar proses pembelajaran dapat berjalan secara optimal.

Menghargai semua jawaban dan hasil analisis dari para peserta didik, bila ada yang salah, tetap akan diberikan reward agar tetap menjaga rasa percaya diri mereka.

\section{Observasi Tindakan Siklus II}

Dalam tahap ini observasi dilakukan untuk melihat serta mengetahui intervensi yang telah dijalankan dalam siklus selanjutnya. Deskripsinya dapat dilihat dalam uraian ini :

\section{Pertemuan Ketiga :}

Dari hasil observasi yang diperoleh oleh peneliti, mulai ada perubahan ke tahap yang lebih baik dibanding siklus terdahulu. Pembelajaran mulai berlangsung dengan aktif, karena mulai ada beberapa peserta didik yang mulai berani terlibat dalam forum diskusi.

\section{Pertemuan Ke Empat :}

Aktivitas pembelajaran semakin menuju ke arah yang lebih baik, dalam pertemuan ini hampir setiap peserta didik memberikan pandangannya terhadap materi kajian yang sedang dibahas, interaksi antar anggota kelompok juga kian meningkat, tiada lagi tipikal one man show di setiap kelompok. Hal ini dapat kita lihat pada tabel 5 . berikut :

\section{Pertemuan Ke Lima :}

Aktivitas pembelajaran di pertemuan ini telah mengalami situasi yang sangat optimal, mayoritas peserta didik telah mengikuti aktivitas pembelajaran dengan amat aktif. Peserta didik kini juga sering memberikan argumen serta tanggapan dengan penguatan dari setiap literatur yang mereka baca.

Peneliti bersama guru duduk bersama melakukan refleksi terhadap pelaksanaan siklus II, dengan paparan sebagai berikut :

a. Aktivitas peserta didik dalam pembelajaran berada pada kategori baik sekali. Hal ini dapat dilihat dari tabel aktivitas peserta didik yang terus mengalami peningkatan dalam proses pembelajaran. Tercapainya aktivitas ini karena dilakukan langkah-langkah antara lain, pada saat pemaparan materi dalam forum diskusi melalui tayangan infocus, peserta didik yang kurang memperhatikan, tiba-tiba diberi teguran oleh guru. Dalam memulai pembelajaran, guru juga memberikan intermezzo yang berkaitan dengan topik pembahasan, hal ini untuk menarik minat peserta didik. Setiap kelompok penyaji juga diwajibkan menayangkan visualisasi (gambar) yang terpaut dengan materi penyajian mereka, hal ini agar mempermudah para peserta didik yang lain untuk menggambarkan situasi pada masa lalu.

b. Konsentrasi peserta didik dalam aktivitas pembelajaran juga kian meningkat, tiada lagi peneliti menemukan peserta didik yang hilang konsentrasinya saat pembelajaran berlangsung. Guru memotivasi peserta didik bahwa setiap materi pembahasan adalah sesuatu hal yang penting dalam memperkaya pengetahuan dan wawasan, terlebih materi pembahasan pada siklus ini peristiwanya belum lama terjadi, maka sangat disayangkan jika mereka kurang fokus saat 
mengkaji materi tersebut. Guru tetap memberikan jokes agar situasi kelas tetap menyenangkan, porsi jokes sendiri disesuaikan dengan porsi waktu, agar tidak banyak waktu terbuang untuk hal diluar aktifitas pembelajaran. Kendala kelelahan akibat problem jam terakhir sudah tidak muncul dalam siklus ini.

c. Tidak seperti di siklus awal, pada siklus kedua, interaksi atau kerjasama antar anggota kelompok juga kian berjalan ke arah yang lebih sempurna, peneliti melihat, kini setiap anggota kelompok memberikan sumbangsih pemikirannya atas hal yang sedang didiskusikan, hilangnya tipikal peserta didik one man show adalah indikasi utama keberhasilan akan hal ini. Pada tahap pendahuluan, guru juga memberikan motivasi serta semangat kepada kelompok penyaji untuk meyakinkan mereka bahwa forum diskusi mereka akan berjalan dengan sukses.

d. Pada siklus kedua, terlihat bahwa keterlibatan peserta didik dalam forum diskusi juga mengalami peningkatan yang sangat signifikan. Kini keterlibatan dalam forum diskusi tidak hanya terfokus kepada beberapa orang yang menyukai mata pelajaran Sejarah. Mayoritas peserta didik mulai berani dalam memberikan argumen, tanggapan serta analisis mereka. Juga hadir sikap toleransi dalam forum tersebut, pertanyaan diberikan atas dasar rasa ingin tahu, bukan untuk menjatuhkan kapasitas (kemampuan) kelompok penyaji. Guru memberikan ruang sebesar-besar-nya agar peserta didik terus mengembangkan sikap berpikir kritisnya, dan hampir setiap pertanyaan yang muncul bersifat investigasi, yang membuat baik penanya maupun penjawab akan memberikan sesuatu yang maksimal dalam argumen dan tanggapan mereka.

Berdasarkan hasil yang telah dicapai pada siklus II ini, maka peneliti bersama guru sepakat untuk menghentikan tindakan penelitian sampai pada siklus ini. Hal ini dikarenakan semua indikator keberhasilan yang ditetapkan untuk masing-masing indikator kemampuan berpikir kritis peserta didik telah dapat terpenuhi.

\section{KESIMPULAN}

Aktivitas peserta didik kelas XII IPS 3 SMA Negeri 42 Jakarta dalam mata pelajaran Sejarah melalui pendekatan pembelajaran konstruktivistik mengalami peningkatan. Aktivitas pembelajaran seperti merumuskan masalah, memberikan argumen atas pertanyaan teman, memberikan tanggapan atas pernyataan teman, melakukan deduksi, melakukan induksi dan menganalisis data, melakukan evaluasi, dan mengambil kesimpulan semuanya mengalami peningkatan. Hal tersebut dapat dilihat pada tabel aktivitas pembelajaran di bab IV. Dari tabel tersebut dapat disimpulkan bahwa kemampuan berpikir kritis peserta didik mengalami peningkatan dalam setiap aktivitas pembelajaran di kelas.

Penerapan pendekatan pembelajaran konstruktivistik dapat meningkatkan hasil belajar Sejarah peserta didik pada kelas XII IPS 3 SMA Negeri 42 Jakarta. Nilai ratarata peserta didik pada siklus I sebesar 88.78, meningkat pada siklus II menjadi 92.57. Rata-rata nilai ulangan harian para peserta didik telah memcapai hasil di atas KKM yang berada di angka 75 . 


\section{IMPLIKASI}

Penerapan pendekatan pembelajaran konstruktivistik dapat meningkatkan kemampuan berpikir kritis dan hasil belajar Sejarah pada peserta didik kelas XII IPS 3 SMA Negeri 42 Jakarta. Penanaman konsep materi melalui pendekatan pembelajaran konstruktivistik dapat mempercepat dan mempermudah pemahaman para peserta didik. Maka, sudah sewajarnyalah bagi setiap guru untuk lebih banyak mencari alternatif pendekatan pembelajaran yang dapat meningkatkan kemampuan berpikir kritis dan hasil belajar para peserta didik. Pendekatan pembelajaran yang tepat akan meningkatkan minat belajar, sehingga peserta didik akan lebih bersemangat, tertarik dan merasa lebih mudah dalam mempelajari mata pelajaran Sejarah, serta tidak jenuh saat proses belajar berlangsung.

\section{Daftar Pustaka}

Arikunto, Suharsimi. Penelitian Tindakan Kelas. Jakarta: Bumi Aksara, 2006.

Basri, Hasan. Paradigma Baru Sistem Pembelajaran. Bandung: Pustaka Setia, 2015.

Gredler, Margaret E. Learning And Instruction: Teori Dan Aplikasi. Jakarta: Prenada, 2011.

Ibnu, Trianto Badar Al-Tabany. Mendesain Model Pembelajaran Inovatif, Progresif, Dan Kontekstual. Jakarta : Prenada, 2014.

Mertler, Craig A. Action Research: Teachers as Research in the Classroom. Los Angeles: Sage, 2009.

Nurhayati, Eti. Psikologi Pendidikan Inovatif. Yogyakarta: Pustaka Pelajar, 2011.
Putrayasa. Ida Bagus. Landasan Pembelajaran. Denpasar: Undiksha Press, 2013.

Rosyada, Dede. Paradigma Pendidikan Demokratis : Sebuah Model Pelibatan Masyarakat Dalam Penyelenggaraan Pendidikan. Jakarta: Prenada, 2007.

Rusman. Model-Model Pembelajaran: Mengembangkan Profesionalisme Guru. Jakarta: Rajagrafindo, 2014.

Rusmono. Strategi Pembelajaran Dengan Problem Based Learning Itu Perlu. Bogor : Ghalia Indonesia, 2012.

Sanjaya, Wina. Penelitian Tindakan Kelas. Jakarta: Kencana, 2009.

Sanjaya, Wina. Strategi Pembelajaran: Berorientasi Standar Proses Pendidikan. Jakarta: Prenada, 2013.

Silberman, Mel. Active Learning: 101 Strategi Pembelajaran Aktif. Yogyakarta: Insan Madani, 2009.

Suyono. Belajar dan Pembelajaran : Teori Dan Konsep Dasar. Bandung: Rosdakarya, 2011.

Thobroni, M. Belajar dan Pembelajaran: Teori Dan Praktek. Yogyakarta: Ar-Ruzz Media, 2015.

Trianto. Penelitian Tindakan Kelas Teori Dan Praktek. Jakarta: Prestasi Pustaka, 2012.

Yamin, Martinis. Desain Pembelajaran Konstruktivistik. Jakarta: Referensi, 2012.

Yaumi, Muhammad. Pembelajaran Berbasis Multiple Intelligences. Jakarta: Dian Rakyat, 2012. 